\title{
ANALISIS KINERJA SUMBER DAYA MANUSIA (SDM) DI PT. RUMEKSA MEKARING SABDA
}

\section{PERFORMANCE ANALYSIS OF HUMAN RESOURCES (HR) IN PT. RUMEKSA MEKARING SABDA}

\author{
RIZKY APRILYAN JABO ${ }^{1 *}$ DAN LASMONO TRI SUNARYANTO ${ }^{2}$ \\ ${ }^{1}$ Program Studi Agribisnis Fakultas Pertanian dan Bisnis, Universitas Kristen Satya Wacana \\ ${ }^{2}$ Staff Pengajar Program Studi Agribisnis, Fakultas Pertanian dan Bisnis, \\ Universitas Kristen Satya Wacana \\ *Email : 522016045@student.uksw.edu
}

\begin{abstract}
ABSTRAK
Tujuan dari penelitian ini adalah untuk mengetahui pengaruh tidak langsung dari reward dan punishment melalui motivasi terhadap kinerja karyawan. Jenis penelitian yang digunakan adalah penelitian kuantitatif. Metode pengambilan data menggunakan simple random sampling, yaitu mengambil sampel secara acak menggunakan undian hingga memenuhi kebutuhan sampel penelitian. Jumlah responden adalah 40 orang. Teknik pengolahan data menggunakan program SPSS for Windows v.21. Teknik analsis data dari penelitian ini antara lain uji validitas, uji reliabilitas, uji asumsi klasik, analisis regresi, uji $\mathrm{T}$ dan Uji F. Hasil penelitian menunjukkan bahwa reward dan punishment memiliki pengaruh secara parsial maupun simultan terhadap motivasi, sedangkan motivasi memiliki pengaruh terhadap kinerja sumber daya manusia.
\end{abstract}

Kata kunci: Pengaruh, Reward, Punishment, Motivasi, Kinerja

\section{ABSTRACT}

The purpose of this study was to determine the indirect effect of reward and punishment through motivation on employee performance. The type of research is quantitative research. The data collection method uses simple random sampling, which is taking a random sample using lottery to meet the needs of the research sample. The number of respondents is 40 people. The data processing technique used SPSS for Windows v.21 programs. Data analysis techniques from this study include validity test, reliability test, classic asumption test, regression analysis, $T$ test and $F$ test. The results show that reward and punishment have a partial or simultaneous effect on motivation, while motivation has an influence on the performance of human resources.

Keyword: Effect, Reward, Punishment, Motivation, Performance.

\section{PENDAHULUAN}

Sumber daya manusia adalah individu yang bekerja di dalam suatu organisasi atau sebuah perusahaan, setiap individu ini memiliki potensi tersendiri, potensi ini akan dimanfaatkan oleh pihak organisasi atau perusahaan dalam mencapai tujuan dari perusahaan tersebut. Dalam menereapkan potensinya tiap individu akan menghasilkan suatu nilai yang disebut dengan kinerja (Sutrisno 2014). Manajemen SDM adalah perencanaan, pengkoordinasian, pelaksanaan dan pengawasan yang diberikan oleh pihak perusahaan terhadap tiap individu (karyawan) yang bekerja untuk perusahaan. Hal ini dikembangkan secara maksimal sehingga tiap individu 
(karyawan) dapat memberikan hasil yang maksimal pula. Hasil yang diberikan oleh tiap individu ini secara umum diartikan dengan kinerja (Mangkunegara 2013).

Kinerja adalah pencapaian hasil dari individu yang bekerja di dalam sebuah perusahaan, pencapaian ini dilakukan dengan wewenang dan tanggung jawab dari individu tersebut (Prawirosentono 2009). Kata kinerja berasal dari kata job performance yang mempunyai arti hasil kerja yang diberikan dari setiap individu yang bekerja di dalam sebuah organisasi atau perusahaan, hasil kerja ini nantinya akan diukur secara kualitas dan kuantitas. Pada saat pemenuhan tugasnya tiap individu dituntut untuk menggunakan ketrampilannya sesuai dengan pekerjaan dan penempatan kerjanya (Mangkunegara 2005). Lebih lanjut Mangkunegara berpendapat bahwa kinerja akan dibagi menjadi dua. Hasil kerja yang berasal hanya dari satu individu dinamakan kinerja individu. Sedangkan hasil kerja yang berasal dari kumpulan beberapa individu disebut dengan kinerja kelompok.

Salah satu faktor yang dapat meningkatkan kinerja yaitu tingginya motivasi karyawan. Motivasi adalah suatu keinginan individu untuk melakukan pekerjaan yang telah ditentukan. Untuk meningkatkan motivasi dapat dilakukan dengan cara pemberian reward (penghargaan) dan punishment (hukuman)(Robbins 2002). Terdapat dua cara agar suatu individu dapat termotivasi. Cara yang pertama yaitu dengan cara melakukan pemenuhan kebutuhan dari individu tersebut. Cara yang kedua yaitu teknik komunikasi persuasif, teknik ini dilakukan dengan cara mempengaruhi pola pikir karyawan. Teknik ini dirumuskan dengan sebutan AIDDAS, yaitu attention (perhatian), interest (minat), desire (hasrat), decision (keputusan), action (tindakan) dan satisfaction (kepuasan). Penerapannya yaitu pertama pihak perusahaan harus memberikan pengertian kepada karyawannya tentang pentingnya tujuan dari suatu pekerjaan sehingga karyawan tersebut muncul hasrat kuat untuk mengambil keputusan dan melakukan tindakan mengenai pekerjaannya agar mencapai tujuan yang telah ditetapkan oleh perusahaan. Dengan demikian karyawan akan bekerja dengan motivasi tinggi sehingga menghasilkan kinerja yang baik dan tingkat kepuasan kerja yang tinggi(Mangkunegara 2005).

Definisi dari reward adalah apresiasi yang diberikan oleh pihak perusahaan kepada karyawannya, untuk mengapresiasi kinerja yang baik (Swastha and Handoko 2012). Agar karyawan termotivasi untuk 
memberikan kinerja yang baik serta memiliki kepuasan kerja salah satu hal yang dapat dilakukan oleh suatu perusahaan adalah dengan memberikan imbalan. Dalam suatu organisasi atau perusahaan reward lebih diartikan ke insentif (Triton 2010).

Punishment merupakan hukuman yang diberikan oleh suatu perusahaan atau organisasi kepada karyawan pelanggar (Mangkunegara 2014).

Setiap perusahaan memiliki cara yang berbeda beda dalam meingkatkan kinerja karyawan. PT. Rumeksa Mekaring Sabda merupakan perusahaan yang menerapkan reward, punishment dan motivasi sebagai alat untuk meningkatkan kinerja karyawannya. Penerapan reward dapat dilihat dari pemberian bonus yang diberikan pihak perusahaan. Salah satu penerapan punishment diterapkan dengan cara ketika terdapat karyawan yang memiliki potongan rambut tidak rapi pada saat itu juga potongan rambut karyawan tersebut langsung dirapikan. Penerapan motivasi dapat dilihat dari dilakukannya morning briefing yang dilakukan setiap pagi. Berdasarkan latar belakang tersebut dapat ditarik dua rumusan masalah dalam penelitian ini, antara lain bagaimana pengaruh reward dan punishment terhadap motivasi kerja karyawan dan bagaimana pengaruh dari motivasi terhadap kinerja karyawan. Tujuan dari penelitian ini adalah mengetahui pengaruh tidak langsung reward dan punishment melalui motivasi terhadap kinerja karyawan.

\section{Hipotesa Penelitian}

$H_{1}$ : reward dan punishment memiliki pengaruh secara tidak langsung melalui motivasi terhadap kinerja karyawan

$H_{2}$ : reward dan punishment tidak memiliki pengaruh secara tidak langsung melalui motivasi terhadap kinerja karyawan.

\section{METODE PENELITIAN}

Jenis penelitian ini adalah penelitian kuantitatif. Penetlitian ini memiliki tujuan untuk menguji hipotesa yang telah ditetapkan yaitu apakah variabel bebas (independent) memiliki pegnaruh terhadap variabel terikat (dependent) melalui variabel intervening. Variabel yang termasuk kedalam variabel bebas yaitu reward dan punishment, variabel yang termasuk kedalam variabel terikat yaitu kinerja karyawan, variabel yang termasuk kedalam variabel intervening yaitu motivasi. Penentuan daerah penelitian dilakukan secara sengaja, daerah penelitian tersebut adalah perusahaan PT. Rumeksa Mekaring Sabda. Sampel yang digunakan 
dalam penelitian ini adalah karyawan yang bekerja di dalam perusahaan PT. Rumeksa Mekaring Sabda sebanyak 40 karyawan. Teknik pengambilan sampel menggunakan teknik simple random sampling, dengan cara menggunakan undian hingga memenuhi kebutuhan sampel penelitian. Teknik pengumpulan data menggunakan teknik penyebaran angket atau kuesioner kepada karyawan yang telah terpilih dalam undian. Pengukuran variabel ini menggunakan skala likert, terdiri atas skor satu hingga lima yang secara berurutan memiliki arti sangat tidak seutuju (STS), tidak setuju (TS), netral (N), setuju (S) dan sangat setuju (SS). Pengolahan data dalam penelitian ini menggunakan program SPSS for Windows v.21. Tahap tahap pengolahan data yang dilakukan dalam penelitian ini antara lain uji validitas, uji reliabilitas, uji asumsi klasik, analisis regresi, uji $\mathrm{T}$ dan uji F

\section{Uji validitas}

Uji validitas dilakukan untuk menguji valid atau tidaknya suatu kuesioner. Kuesioner dikatakan valid jika pertanyaan pada kuesioner mampu untuk mengungkapkan sesuatu yang akan diukur oleh kuesioner tersebut(Ghozali 2012). Uji validitas dalam penelitian ini menggunakan korelasi Product Moment dengan rumus sebagai berikut (Sugiyono 2016):

$$
r_{x y}=\frac{\mathrm{N} \sum \mathrm{XY}-\left(\sum \mathrm{X}\right)\left(\sum \mathrm{Y}\right)}{\sqrt{\left\{\mathrm { N } ( \sum \mathrm { X } ^ { 2 ) - ( \sum \mathrm { X } ) ^ { 2 } } \} \left\{\mathrm{N}\left(\sum \mathrm{Y}^{2}\right)-\left(\sum \mathrm{Y}\right)^{2}\right.\right.}}
$$

Keterangan

$r_{x y}=$ koefisien korelasi antara variabel $\mathrm{x}$ dan $\mathrm{y}$

$\mathrm{Y}=$ total skor yang diperoleh dari seluruh item

$\mathrm{X}=$ Skor variabel (jawaban responden)

$\mathrm{N}=$ Jumlah respoden

\section{Uji reliabilitas}

dilakukan untuk menguji apakah sumber kuesioner reliabel atau tidak. Suatu kuesioner dikatakan reliabel atau handal jika jawaban seseorang terhadap pernyataan adalah konsisten atau stabil dari waktu ke waktu (Ghozali 2012). Suatu variable dikatakan reliabel jika memberikan nilai Crobanch Alpha lebih dari 0,60. Dalam penelitian ini teknik untuk menghitung indeks reliabilitas yaitu dengan teknik Cronbach dengan menggunakan koefisien alpa $(\alpha)$ (Arikunto, 2013).

$$
r_{i}=\left[\frac{k}{k-1}\right]\left[1-\frac{\Sigma \sigma b^{2}}{\sigma_{t}^{2}}\right]
$$

dimana :

$r_{i} \quad=$ Koefisien reliabilitas

$\mathrm{k}=$ Banyak butir pertanyaan atau persyaratan. 
$\sum \sigma_{b}^{2}=$ Jumlah varian butir tiap pertanyaan

$\sigma_{t}^{2} \quad=$ Varian total

\section{Uji asumsi klasik}

uji yang dilakukan dengan menerapkan 3 cara uji, yaitu uji normalitas, uji multikolinearitas dan uji heterokedastisitas. Data dikatakan normal jika nilai Asymp.Sig.(2 tailed) > 0,05 dengan menggunakan uji KolmogrofSimirnov, sedangkan data tidak mengalami heterokedastisitas apabila di dalam uji Glejser nilai signifikansi melebihi 5\% atau 0,05 (Ghozali 2013). Data dikatakan tidak mengalami multikolinearitas apabila nilai VIF (Variance Inflation Factor) $<10$ (Husein 2011).

\section{Analisis Regresi}

Dalam penelitian ini dilakukan 2 kali analisis regresi, yaitu regresi linier berganda dan regresi linier sederhana. Analisis regresi linier berganda yaitu analisis yang dilakukan untuk melihat pengaruh yang diberikan dua atau lebih variabel independen terhadap variabel dependen (Yamin, Rachmach, and Kurniawan 2011). Persamaan atau model regresi yang digunakan dalam analisis regresi linier berganda pada penelitian ini adalah sebagai berikut

$$
\mathrm{Y}=\mathrm{a}+\mathrm{b}_{1} \mathrm{X}_{1}+\mathrm{b}_{2} \mathrm{X}_{2}+\mathrm{e}
$$

Keterangan:

$$
\begin{aligned}
& \mathrm{Y}=\text { motivasi kerja } \\
& \mathrm{a} \quad=\text { konstanta } \\
& \mathrm{b} 1 \quad=\text { koefisien regresi dari } \mathrm{X} 1 \\
& \text { (reward) }
\end{aligned}
$$

$\mathrm{b} 2=$ koefisien regresi dari $\mathrm{X} 2$ (punishment)

$$
\begin{array}{ll}
\mathrm{X} 1 & =\text { reward } \\
\mathrm{X} 2 & =\text { punishment } \\
\mathrm{e} & =\text { error }
\end{array}
$$

Analisis regresi linier sederhana yaitu anlisis yang dilakukan untuk melihat apakah terdapat hubungan fungsional ataupun kausal dari satu variabel independen dengan satu variabel dependen (Sugiyono 2014). Persamaan atau model regresi dari analisis ini adalah sebagai berikut.

$$
\mathrm{Y}=\mathrm{a}+\mathrm{b}_{1} \mathrm{X}_{1}+\mathrm{e}
$$

Keterangan:

$$
\begin{aligned}
& \mathrm{Y}=\text { motivasi kerja } \\
& \mathrm{a} \quad=\text { konstanta } \\
& \mathrm{b} 1 \quad=\text { koefisien regresi dari } \mathrm{X} 1 \\
& \text { (reward) } \\
& \mathrm{X} 1 \quad=\text { reward } \\
& \mathrm{e} \quad=\text { error }
\end{aligned}
$$

\section{Uji T dan Uji F}

Uji t dilakukan untuk mengetahui bagaimana pengaruh tiap tiap variabel independen terhadap variabel dependen. Variabel independen dikatakan memiliki pengaruh terhadap variabel independen 
apabila nilai siginifikan $<0,05$ (Ghozali 2013). Uji F adalah uji yang dilakukan untuk mengetahui apakah variabel bebas yang dimaksudkan memiliki pengaruh secara simultan atau bersama sama terhadap variabel dependen. Variabel indedependen dikatakan memiliki pengaruh simultan terhadap variabel dependen jika nilai signifikan $<0,05$ (Ghozali 2013).

\section{HASIL DAN PEMBAHASAN} Uji Validitas

Untuk mengukur valid tidaknya suatu kuesioner dapat membandingkan $r$ hitung dengan $r$ tabel dengan degree of freedom $=\mathrm{N}-2, \mathrm{~N}$ sendiri adalah jumlah responden penelitian dan $\alpha=0,05$. Kuesioner dikatakan valid jika nilai $r$ hitung > r tabel (Ghozali 2012). pengukuran uji validitas dapat menggunakan program SPSS for Windows v.21, dapat dilihat dari nilai pearson correlation indikator terhadap variabel. Berikut adalah hasil output dari penghitungan validitas penelitian dengan menggunakan SPSS for Windows v.21.
Tabel 1 : Uji Validitas

\begin{tabular}{ccc}
\hline $\begin{array}{c}\text { Indikator } \\
\text { Variabel }\end{array}$ & r Hitung & R tabel \\
\hline X11 & & \\
X13 & 0,711 & 0,312 \\
X14 & 0,758 & 0,312 \\
X21 & 0,830 & 0,312 \\
X23 & 0,813 & 0,312 \\
X24 & 0,836 & 0,312 \\
X31 & 0,746 & 0,312 \\
X33 & 0,746 & 0,312 \\
X34 & 0,572 & 0,312 \\
X36 & 0,600 & 0,312 \\
X37 & 0,692 & 0,312 \\
X38 & 0,641 & 0,312 \\
X39 & 0,620 & 0,312 \\
Y41 & 0,635 & 0,312 \\
Y42 & 0,756 & 0,312 \\
\hline Sumber : Data primer yang telah diolah, 2021
\end{tabular}

Jumlah responden dari penelitian ini sebanyak 40 responden, sehingga diperoleh degree of freedom sebesar 38 . Berdasarkan degree of freedom dan nilai $\alpha$ sebesar 0.05, maka dapat diperoleh nilai $\mathrm{r}$ tabel sebesar 0,312. Kuesioner valid jika nilai $r$ hitung > r tabel (Ghozali 2012). Berdasarkan hal ini dapat dilihat dari hasil output diatas bahwa semua indikator yang terdapat didalam kuesioner dapat dikatakan valid karena semua indikator tersebut memiliki nilai $r$ hitung $>r$ tabel.

\section{Uji Reliabilitas}

Berikut adalah hasil output dari penghitungan uji reliabilitas menggunakan SPSS for Windows v. 21. 
Tabel 2 : Uji Reliabilitas

\begin{tabular}{lc}
\hline Variabel & Crobanch Alpha \\
\hline X1 & 0,811 \\
X2 & 0,825 \\
X3 & 0,758 \\
Y & 0,805 \\
\hline \multicolumn{2}{c}{ Sumber : Data primer yang telah diolah, 2021 }
\end{tabular}

Sumber : Data primer yang telah diolah, 2021

Suatu variabel dapat dikatakan reliabel atau handal jika nilai crobanch alpha dari variabel tersebut $>0,6$ (Ghozali 2012). Berdasarkan hal tersebut dapat disimpulkan dari hasil output diatas bahwa semua variabel yang terdapat didalam penelitian ini reliabel atau handal. Hal ini dikarenakan nilai crobanch alpha milik semua variabel $>0,6$.

\section{Uji Asumsi Klasik}

a. Uji Normalitas

Uji normalitas dapat menggunakan aplikasi atau program SPSS for Windows v.21. Berikut adalah hasil output dari uji normalitas menggunakan program SPSS for Windows v. 21

\section{Tabel 3 : Uji Normalitas}

One Sample Kolmogorov Smirnov Test

Asymp. Sig. (2-tailed) $\quad 0,767$

Sumber : Data primer yang telah diolah, 2021

Melakukan uji normalitas untuk melihat apakah model regresi berdistribusi normal atau tidak dapat dilihat dari angka Asymp. Sig. (2-tailed) (Ghozali 2013). Kriteria berdisribusi normal terpenuhi jika nilai Asymp. Sig. (2-tailed) > 0,05. diatas menunjukkan bahwa model regresi dari penelitian ini dapat dikatakan berdistribusi normal, karena nilai dari Asymp. Sig. (2-tailed) sebesar 0,767 > 0,05 .

Berdasarkan hal tersebut hasil output Uji Heterokedastisitas

Uji heterokedastisitas dilakukan untuk mengetahui apakah di dalam model regresi terdapat perbedaan antara variance dari residual pengamat satu dengan yang lain, jika terjadi perbedaan maka model regresi tersebut mengalami heterokedastisitas jika tidak maka dinamakan homokedastisitas (Ghozali 2013). Untuk melakukan uji heterokedastisitas dapat menggunakan program SPSS for Windows v.21. Berikut adalah uji heterokedastisitas dengan menggunakan program SPSS for Windows v. 21 .

Tabel 4 : Tabel Uji Heterokedastisitas

\begin{tabular}{lc}
\hline Variabel Penelitian & Sig. \\
\hline Reward $\left(\mathrm{X}_{1}\right)$ & 0,148 \\
Punishment $\left(\mathrm{X}_{2}\right)$ & 0,930 \\
Motivasi $\left(\mathrm{X}_{3}\right)$ & 0,678 \\
\hline \multicolumn{2}{c}{ Sumber : Data primer yang telah diolah, 2021}
\end{tabular}

Model regresi tidak mengalami gejala heterokedastisitas jika nilai signifikansi > dari 0,05 (Ghozali 2013). Nilai signifikansi tersebut dapat dilihat dari hasil analisis regresi nilai absolut 
residualnya. Berdasarkan hal tersebut dapat dilihat dari hasil output diatas bahwa model regresi dari penelitian ini tidak terjadi gejala heterokedastisitas, karena nilai signifikansi dari setiap variabel lebih besar dari 0,05. Nilai signifikansi dari setiap variabel secara berurutan adalah 0,148; 0,930 dan 0,678.

b. Uji Multikolinearitas asumsi klasik yang digunakan untuk melihat apakah terdapat korelasi antara satu variabel independen dengan variabel independen lainnya. Model atau persamaan regresi yang baik adalah model regresi yang tidak terdapat korelasi antara satu variabel independen satu dengan yang lain (Husein 2011). Untuk melakukan uji multikolinearitas dapat menggunakan program SPSS for Windows v.21. berikut adalah hasil uji multikolinearitas dengan menggunakan program SPSS for Windows v. 21 .

Tabel 5 : Uji Multikolinearitas

\begin{tabular}{lcc}
\hline Variabel & \multicolumn{2}{c}{ Collinearity Statistics } \\
\cline { 2 - 3 } & Tolerance & VIF \\
\hline Reward $\left(\mathrm{X}_{1}\right)$ & 0,618 & 1,618 \\
Punishment $\left(\mathrm{X}_{2}\right)$ & 0,503 & 1,987 \\
Motivasi $\left(\mathrm{X}_{3}\right)$ & 0,360 & 2,774 \\
\hline
\end{tabular}

Sumber : data primer yang telah diolah, 2021

Berdasarkan hasil uji diatas dapat dilihat nilai tolerance dari setiap variabel secara berurutan adalah 0,$618 ; 0,503$ dan 0,360 sedangkan untuk nilai VIF secara berurutan adalah 1,618; 1,987 dan 2,774.

\section{Analisis Regresi}

Dalam penelitian ini dilakukan dua tahap analisis regresi yaitu analisis regresi linier berganda dan analisis linier sederhana. Hal ini dikarenakan di dalam penelitian ini yang akan diteliti oleh peniliti adalah pengaruh secara tidak langsung dari reward dan punishment terhadap kinerja karyawan melalui motivasi. Berikut adalah hasil dan penjelasan dari tiap analisis regresi dengan menggunakan program SPSS for Windows v. 21 .

a. Analisis Regresi Linier Berganda

Dalam analisis tahap pertama ini variabel yang dijadikan variabel dependen atau variabel yang akan di regresi adalah motivasi dengan reward dan punishment sebagai variabel independennya. Analisis ini dilakukan dengan bantuan program SPSS for Windows v.21. berikut adalah hasil output dari analisis yang telah dilakukan sebelumnya.

Tabel 6 : Analisis Regresi Linier Berganda

\begin{tabular}{lccc}
\hline Variabel & $\mathrm{B}$ & $\mathrm{T}$ & Sig. \\
\hline Konstanta & 6,249 & & \\
Reward $\left(\mathrm{X}_{1}\right)$ & 0,761 & 3,950 &, 000 \\
Punishment $\left(\mathrm{X}_{2}\right)$ & 1,085 & 5,225 &, 000 \\
\hline \multicolumn{4}{l}{ Sumber : Data primer yang telah diolah, 2021}
\end{tabular}


Persamaan regresi linier berganda dapat ditulis dengan cara sebagai berikut (Yamin et al. 2011).

$$
\mathrm{Y}=\mathrm{a}+\mathrm{b}_{1} \mathrm{X}_{1}+\mathrm{b}_{2} \mathrm{X}_{2}+\mathrm{e}
$$

Berdasarkan hal tersebut maka dapat

dibuat persamaan regresi sebagai berikut.

$$
\mathrm{Y}=6,249+0,761 \mathrm{X}_{1}+1,085 \mathrm{X}_{2}
$$

Persamaan diatas dapat di interpretasikan sebagai berikut.

i. Nilai konstanta (a) dari persamaan tersebut adalah 6,249 maka jika variabel reward $\left(\mathrm{X}_{1}\right)$ dan punishment $\left(\mathrm{X}_{2}\right)$ tidak berpengaruh terhadap motivasi maka nilai $\mathrm{Y}$ akan tetap sebesar 6,249 tanpa mengalami perubahan apapun.

ii. Nilai dari koefisien regresi satu $\left(b_{1}\right)$ adalah 0,761 maka setiap ada penambahan sebesar satu satuan variabel reward $\left(\mathrm{X}_{1}\right)$ maka motivasi (Y) akan terpengaruh atau bertambah sebesar 0,761 .

iii. Nilai dari koefisien regresi dua $\left(b_{2}\right)$ adalah 1,085 maka setiap ada penambahan sebesar satu satuan variabel punishment $\left(\mathrm{X}_{2}\right)$ maka motivasi (Y) akan terpengaruh atau bertambah sebesar 1,085.

\section{b. Analisis Regresi Linier Sederhana}

Dalam analisis tahap dua ini hal pertama yang harus dilakukan adalah melakukan penghitungan dari persamaan sebelumnya dengan mempertimbangkan bahwa terdapat pengaruh antara reward (X1) dan punishment (X2) terhadap motivasi (X3). Setelah melakukan pertimbangan maka selanjutnya adalah memasukkan nilai masing masing dari variabel independen kedalam rumus tersebut, lalu menjumlahkan sesuai dengan persamaan tersebut. Hasil dari penjumlahan tersebut adalah sebagai berikut.

\begin{tabular}{|c|c|c|c|}
\hline $\mathrm{X}_{3}$ lama & $\mathbf{X}_{3}$ baru & $X_{3}$ lama & $\mathrm{X}_{3}$ baru \\
\hline 34 & 34,5 & 34 & 33,5 \\
\hline 33 & 38,4 & 32 & 30,2 \\
\hline 36 & 36,5 & 31 & 32,9 \\
\hline 39 & 35,6 & 34 & 35,0 \\
\hline 45 & 42,4 & 36 & 34,3 \\
\hline 45 & 43,2 & 42 & 34,7 \\
\hline 33 & 34,7 & 36 & 35,8 \\
\hline 26 & 31,0 & 27 & 28,4 \\
\hline 34 & 37,0 & 36 & 35,8 \\
\hline 34 & 32,9 & 35 & 37,6 \\
\hline 34 & 32,4 & 38 & 36,2 \\
\hline 40 & 39,9 & 38 & 36,5 \\
\hline 39 & 39,5 & 37 & 35,8 \\
\hline 41 & 39,5 & 35 & 32,4 \\
\hline 41 & 39,5 & 36 & 37,5 \\
\hline 38 & 39,5 & 40 & 39,8 \\
\hline 35 & 35,8 & 41 & 39,5 \\
\hline 34 & 36,5 & 35 & 40,2 \\
\hline 37 & 38,3 & 41 & 39,5 \\
\hline 37 & 37,2 & 39 & 38,4 \\
\hline
\end{tabular}

\section{Tabel 7 : Penjumlah $X_{3}$ Baru}

Setelah melakukan penjumlahan dan mendapatkan hasil seperti diatas selanjutnya yang dilakukan adalah 
melakukan analisis regresi kedua dengan motivasi $\left(\mathrm{X}_{3}\right)$ sebagai variabel independen dan kinerja karyawan $(\mathrm{Y})$ sebagai variabel dependen. Berikut adalah hasil dari analisis regresi yang telah dilakukan sebelumnya.

Tabel 8. Analisis regresi linier sederhana

\begin{tabular}{lccc}
\hline Variabel & $\mathrm{B}$ & $\mathrm{T}$ & Sig. \\
\hline Konstanta & 0,030 & & \\
Motivasi & 0,222 & 4,713 &, 000 \\
\hline
\end{tabular}

Melakukan analisis regresi linier sederhana dapat disimpulkan suatu persamaan tersebut sebagai berikut (Sugiyono 2016).

$$
\mathrm{Y}=\mathrm{a}+\mathrm{b}_{1} \mathrm{X}_{1}+\mathrm{e}
$$

Berdasarkan hal tersebut maka dalam analisis regresi linier sederhana pada penelitian ini dapat disimpulkan suatu persamaan sebagai berikut.

$$
\mathrm{Y}=0,030+0,222 \mathrm{X}_{1}
$$

Persamaan tersebut dapat diinterpretasikan sebagai berikut.

i. Nilai konstanta (a) dari persamaan tersebut adalah 0,030 maka jika variabel motivasi $\left(\mathrm{X}_{3}\right)$ tidak berpengaruh terhadap motivasi maka nilai $\mathrm{Y}$ akan tetap sebesar 0,030 tanpa mengalami perubahan apapun.

ii. Nilai dari koefisien regresi $\left(b_{1}\right)$ adalah 0,222 maka setiap ada penambahan sebesar satu satuan variabel motivasi $\left(\mathrm{X}_{3}\right)$ maka motivasi (Y) akan terpengaruh atau bertambah sebesar 0,222 .

\section{Uji T}

Dalam penelitian ini dilakukan dua uji t hal ini disebabkan karena terdapat dua analisis regresi, maka harus dilihat apakah pada tiap analisis regresi variabel independennya mempunyai pengaruh terhadap variabel dependen. Uji t pada penelitian ini adalah sebagai berikut.

a. Uji t pada analisis regresi linier berganda

Uji t dapat dilihat dari hasil analisis regresi linier berganda yang dilakukan dengan program SPSS for Windows v.21. hasil yang didapatkan adalah sebagai berikut.

Tabel 9. Uji T Analisis Regresi Linier

\begin{tabular}{lcc}
\multicolumn{2}{c}{ Berganda } & \\
\hline Variabel & $\mathrm{T}$ & Sig. \\
\hline Konstanta & & \\
Reward $\left(\mathrm{X}_{1}\right)$ & 3,950 &, 000 \\
Punishment $\left(\mathrm{X}_{2}\right)$ & 5,225 &, 000 \\
\hline
\end{tabular}

Sumber : Data primer yang telah diolah, 2021

Variabel independen memiliki pengaruh terhadap variabel dependen jika nilai signifikansi (Sig.) dari variabel independen tersebut $<0,05$ (Ghozali 2013). Berdasarkan hal tersebut maka dapat dikatakan variabel independen reward (X1) dan punishment (X2) memiliki pengaruh terhadap variabel 
dependen motivasi (X3). Hal ini dikarenekan nilai signifikansi dari tiap variabel independen $<0,05$ dengan nilai signifikansi dari variabel independen secara berurutan adalah ,000.

b. Uji $\mathrm{t}$ pada analisis regresi linier sederhana

Uji t dapat dilihat dari hasil analisis regresi linier berganda yang dilakukan dengan program SPSS for Windows v.21. hasil yang didapatkan adalah sebagai berikut.

Tabel 10 . Uji T Analisi Regresi Linier

\begin{tabular}{lcc}
\multicolumn{3}{c}{ Sederhana } \\
\hline Variabel & $\mathrm{T}$ & Sig. \\
\hline $\begin{array}{l}\text { Konstanta } \\
\text { Motivasi }\left(\mathrm{X}_{3}\right)\end{array}$ & 4,713 &, 000 \\
\hline
\end{tabular}

Sumber : Data primer yang telah diolah, 2021

Variabel independen memiliki pengaruh terhadap variabel dependen jika nilai signifikansi (Sig.) dari variabel independen tersebut $<0,05$ (Ghozali 2013). Berdasarkan hal tersebut maka dapat dikatakan variabel independen motivasi (X3) memiliki pengaruh terhadap variabel dependen kinerja karyawan (Y). Hal ini dikarenekan nilai signifikansi dari tiap variabel independen $<0,05$ dengan nilai signifikansi dari variabel independen secara berurutan adalah ,000.

\section{Uji F}

Berbeda dengan uji t sebelumnya, uji f pada penelitian ini hanya dilakukan satu kali, hal ini dikarenakan hanya pada tahap pertama terdapat dua variabel independen. Pada tahap kedua hanya terdapat satu variabel independen sehingga tidak dapat dilakukan uji f. Uji f pada penelitian ini dilakukan dengan cara menggunakan program SPSS for Windows v.21. berikut adalah hasil dari analisis yang telah dilakukan sebelumnya.

\begin{tabular}{llllll}
\multicolumn{2}{l}{ Tabel 11. Uji F } & & & & \\
\hline Model & $\begin{array}{l}\text { Sum of } \\
\text { squares }\end{array}$ & Df & $\begin{array}{c}\text { Mean } \\
\text { square }\end{array}$ & F & Sig. \\
\hline Regression & 406,663 & 2 & 203,331 & 32,819 &, 000 \\
\hline \multicolumn{2}{c}{ Sumber : Data primer yang telah diolah, 2021}
\end{tabular}

Pada hasil analisis diatas yang berperan menjadi variabel independen dalah reward (X1) dan punishment (X2), sedangkan yang menjadi variabel dependen adalah motivasi (X3). Variabel independen dapat dikatakan berpengaruh secara simultan jika nilai signifikansi dari uji f < 0,05 (Ghozali 2013). Berdasarkan hal tersebut dapat disimpulkan bahwa variabel independen berpengaruh secara simultan terhadap variabel dependen, hal ini dikarenakan nilai signifikansi dari variabel independen $<0,05$ dengan nilai signifikansinya adalah ,000 
Pengaruh reward terhadap motivasi.

Berdasarkan hasil analisis pada tabel 9 variabel reward memiliki nilai signifikansi yang lebih kecil dari 0,05 dengan nilai ,000. Menurut Ghozali (2013), variabel reward memiliki pengaruh terhadap motivasi. Tenaga kerja atau karyawan yang bekerja didalam PT. Rumeksa Mekaring Sabda banyak berpendapat bahwa memang jika mendapatkan reward dari pihak manajemen perusahaan maka akan meningkatkan motivasi untuk melakukan pekerjaan dengan baik, terdapat pula pendapat bahwa pemberian reward ini dapat meningkatkan motivasi tenaga kerja untuk melakukan pekerjaaan yang lebih baik dari tenaga kerja lainnya yang dapat dikatakan bersaing secara sehat untuk mendapatkan reward dari pihak manajemen. Hal ini sejalan dengan pendapat Triton (2010) bahwa tenaga kerja akan merasa termotivasi untuk melakukan atau memberikan kinerja yang baik jika mendapatkan imbalan atau reward dari pihak perusahaan.

\section{Pengaruh variabel punishement} terhadap motivasi.

Berdasarkan hasil analisis pada tabel 9 variabel punishment memiliki nilai signifikansi yang lebih kecil dari 0,05 dengan nilai ,000. Menurut Ghozali
(2013), variabel punishment memiliki pengaruh terhadap motivasi. PT. Rumeksa Mekaring Sabda merupakan perusahaan yang menerapkan punishment atau hukuman atau sanksi terhadap tenaga kerjanya yang melakukan pelanggaran aturan atau kinerja yang diberikan tidak sesuai dengan harapan dari pihak perusahaan. Hal ini telah ditetapkan oleh pihak manajemen perusahaan serta telah disetujui oleh semua tenaga kerja. Pihak manajemen perusahaan mengatakan hukuman atau sanksi yang diberikan kepada pelanggar aturan bermacam macam. Salah satu hukuman yang diberikan tenaga kerja yang melanggar adalah melakukan pemotongan rambut ditempat, pemotongan rambut ditempat dilakukan karena tenaga kerja melanggar aturan gaya potongan rambut yang telah ditetapkan. Selain hukuman tersebut pihak manajemen juga mengatakan bahwa hukuman yang diberikan surat peringatan, surat peringatan tersebut diberikan kepada tenaga kerja yang memiliki kinerja buruk. jika setelah menerima surat tersebut kinerja dari tenaga kerja tersebut tidak terdapat peningkatan maka pihak perusahaan akan memberikan hukuman yang sesuai dengan kontrak. Para tenaga kerja di perusahaan ini juga mengatakan bahwa hukuman atau sanksi yang 
diberikan kepada mereka dapat terlihat secara nyata sehingga para tenaga kerja merasa termotivasi untuk memberikan kinerja yang baik agar tidak menerima hukuman. Hal ini sejalan dengan pendapat dari Mangkunegara (2014) bahwa karyawan akan termotivasi untuk melakukan disiplin kerja sehingga menghaasilkan kinerja yang baik.

Pengaruh variabel motivasi terhadap kinerja.

Berdasarkan hasil analisis pada tabel 10 variabel motivasi memiliki nilai signifikansi yang lebih kecil dari 0,05 dengan nilai ,000. Menurut Ghozali (2013), variabel motivasi memiliki pengaruh terhadap kinerja. Para tenaga kerja atau karyawan yang bekerja didalam PT. Rumeksa Mekaring Sabda berpendapat bahwa memang untuk memberikan kinerja yang baik membutuhkan motivasi yang baik pula, menurut tenaga kerja agar mereka tetap termotivasi dalam melakukan pekerjaannya dibutuhkan pemberian reward. Pihak manajemen juga mengatakan bahwa selain reward, punishment juga dapat menambah motivasi dari para tenaga kerja untuk melakukan kinerja yang baik sesuai dengan harapan perusahaan. Hal ini sejalan dengan pendapat Mangkunegara (2005) bahwa untuk melakukan kinerja yang baik para tenaga kerja butuh mempertahankan motivasinya dengan cara pemberian reward dan punishment.

\section{KESIMPULAN DAN SARAN}

\section{Kesimpulan}

a. Reward dan punishment pada penelitian ini dapat dikatakan memiliki pengaruh terhadap variabel intervening yaitu variabel motivasi. Hal ini dapat dilihat dari uji T dan uji F yang telah dilakukan, hasil dari kedua uji tersebut menunjukkan nilai signifikansi $<0,05$ maka variabel independen memiliki pengaruh terhadap variabel dependen baik secara parsial maupun simultan.

b. Motivasi pada penelitian ini dapat dikatakan memiliki pengaruh terhadap variabel kinerja. Hal ini dapat dilihat dari uji $\mathrm{T}$ yang telah dilakukan, hasil dari uji tersebut menunjukkan nilai signifikansi < 0,05 maka variabel independen memiliki pengaruh terhadap variabel dependen.

\section{Saran}

Saran yang dapat diberikan adalah agar para karyawan atau sumber daya manusia perusahaan PT. Rumeksa Mekaring Sabda tetap memberikan kinerja yang baik diharapkan pihak manajemen 
dari perusahaan tersebut tetap menerapkan pemberian reward dan punishment secara rutin

\section{DAFTAR PUSTAKA}

Ghozali, Imam. 2012. “Analisis Multivariate Dengan Program IBM SPSS."

Ghozali, Imam. 2013. Aplikasi Analisis Multivariate Dengan Program IBM SPSS 21 Update PLS Regresi. Semarang: Badan Penerbit Universitas Diponegoro.

Husein, Umar. 2011. Metode Penelitian Untuk Skripsi Dan Tesis Bisnis Edisi 11. Jakarta: PT. Raja Grafindo Persada.

Mangkunegara, A. A. Anwar Prabu. 2005. Manajemen Sumber Daya Manusia Perusahaan. Bandung: PT. Remaja Rosda Karya.

Mangkunegara, A. A. Anwar Prabu. 2013. Manajemen Sumber Daya Manusia Perusahaan. Bandung: PT. Remaja Rosda Karya.

Mangkunegara, A. A. Anwar Prabu. 2014. Manajemen Sumber Daya Manusia. Bandung: PT. Remaja Rosda Karya.

Prawirosentono, Suyadi. 2009. Manajemen Sumber Daya Manusia Kebijakan Kinerja Karyawan (Era Perdagangan Bebas Dunia). 2nd ed. Yogyakarta: BPFE-Yogyakarta.
Robbins, Stephen P. 2002. Essentials of Organizational Behavior (Terjemahan), Edisi Kelima. Jakarta: Erlangga.

Sugiyono. 2014. Metode Penelitian Kuantitatif, Kualitatif Dan R\&D. Bandung: Alfabeta.

Sugiyono. 2016. "Metode Penelitian Kuantitatif Kualitataif Dan Kombinasi (Mixed Methods)." Journal of Chemical Information and Modeling. doi: 10.1017/CBO9781107415324.004.

Suharsimi, Arikunto. 2013. "Prosedur Penelitian: Suatu Pendekatan Praktik (Edisi Revisi).” Jakarta: Rineka Cipta. doi: 10.1017/CBO9781107415324.004.

Sutrisno, Sugeng. 2014. "Pengaruh Disiplin Kerja Dan Motivasi Kerja Terhadap Kinerja Pegawai Negeri Sipil (Studi Di Kantor Dinas Sosial Provinsi Jawa Tengah)." Jurnal Ilmiah Dinamika Ekonomi Dan Bisnis.

Swastha, Basu Dharmmesta, and Hani Handoko. 2012. Manajemen Pemasaran Analisis Perilaku Konsumen. Edisi Pertama.

Triton, Pb. 2010. Manajemen Sumber Daya Manusia. Jakarta: Oryza.

Yamin, Sofyan, Lien A. Rachmach, and Heri Kurniawan. 2011. Regresi Dan Korelasi Dalam Genggaman Anda. edited by D. A. Halim. Jakarta: Salemba Empat. 